\title{
THEODORE ROOSEVELT, THE U.S. NAVY, AND THE SPANISH-AMERICAN WAR
}




\section{The Franklin and Eleanor Roosevelt Institute Series on Diplomatic and Economic History}

General Editors: Arthur M. Schlesinger, Jr., William J. vanden Heuvel, and Douglas Brinkley

FDR AND HIS CONTEMPORARIES

FOREIGN PERCEPTIONS OF

an AMERICAN PRESIDENT

Edited by Cornelis A. van Minnen

and John F. Sears

NATO: THE FOUNDING

OF THE ATLANTIC ALLIANCE

AND THE INTEGRATION

OF EUROPE

Edited by Francis H. Heller

and John R. Gillingham

AMERICA UNBOUND

WORLD WAR II AND THE MAKING

OF A SUPERPOWER

Edited by Warren F. Kimball

THE ORIGINS OF U.S. NUCLEAR

STRATEGY, 1945-1953

Samuel R. Williamson, Jr. and

Steven L. Rearden

\section{AMERICAN DIPLOMATS IN}

THE NETHERLANDS, 1815-50

Cornelis A. van Minnen

EISENHOWER, KENNEDY, AND

THE UNITED STATES OF EUROPE

Pascaline Winand

\section{ALLIES AT WAR}

THE SOVIET, AMERICAN, AND BRITISH EXPERIENCE, 1939-1945

Edited by David Reynolds,

Warren F. Kimball, and A. O. Chubarian

THE ATLANTIC CHARTER

Edited by Douglas Brinkley and

David R. Facey-Crowther

PEARL HARBOR REVISITED

Edited by Robert W. Love, Jr.
FDR AND THE HOLOCAUST

Edited by Verne W. Newton

THE UNITED STATES AND THE

INTEGRATION OF EUROPE

LEGACIES OF THE POSTWAR ERA

Edited by Francis $\mathrm{H}$. Heller and

John R. Gillingham

ADENAUER AND KENNEDY

A STUDY IN GERMAN-AMERICAN RELATIONS

Frank A. Mayer

THEODORE ROOSEVELT AND

THE BRITISH EMPIRE

A StUdy IN PrEsidential StateCrafT

William N. Tilchin

TARIFFS, TRADE AND EUROPEAN

INTEGRATION, 1947-1957

FroM STUDY GROUP TO COMMON MARKET

Wendy Asbeek Brusse

SUMNER WELLES

FDR's GLOBAL STRATEGIST

A Biography by Benjamin Welles

THE NEW DEAL AND PUBLIC POLICY

Edited by Byron W. Daynes, William D.

Pederson, and Michael P. Riccards

WORLD WAR II IN EUROPE

Edited by Charles F. Brower

FDR AND THE U.S. NAVY

Edward J. Marolda

THE SECOND QUEBEC

CONFERENCE REVISITED

Edited by David B. Woolner

THEODORE ROOSEVELT, THE U.S. NAVY, AND THE SPANISH-AMERICAN WAR

Edited by Edward J. Marolda 


\title{
THEODORE ROOSEVELT, THE U.S. NAVY, AND THE SPANISH-AMERICAN WAR
}

\author{
EDITED BY \\ EDWARD J. MAROLDA
}




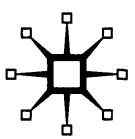

THEODORE RoOSEVELT, THE U.S. NAVY, AND THE SPANISH-AMERICAN WAR C EDWARD J. MAROLDA, 2001

Softcover reprint of the hardcover 1st edition 2001 978-0-312-24023-3

All rights reserved. No part of this book may be used or reproduced in any manner whatsoever without written permission except in the case of brief quotations embodied in critical articles or reviews.

First published 2001 by PALGRAVE ${ }^{\mathrm{TM}}$

175 Fifth Avenue, New York, N.Y.10010 and

Houndmills, Basingstoke, Hampshire RG21 6XS.

Companies and representatives throughout the world

PALGRAVE is the new global publishing imprint of St. Martin's Press LLC Scholarly and Reference Division and Palgrave Publishers Ltd (formerly Macmillan Press Ltd).

\section{ISBN 978-1-349-63344-9 ISBN 978-1-137-05501-9 (eBook)}

DOI 10.1007/978-1-137-05501-9

\section{Library of Congress Cataloging-in-Publication Data}

Theodore Roosevelt, the U.S. Navy, and the Spanish-American War / edited by Edward J. Marolda.

p. $\mathrm{cm}$.

Papers originally presented at a symposium held at the U.S. Navy Memorial's Heritage

Center, Washington, D.C., Oct. 21, 1998.

Includes bibliographical references and index.

1. Spanish-American War, 1898-Naval operations-Congresses. 2. United States. Navy-History-Spanish-American War, 1898-Congresses.

3. Roosevelt, Theodore, 1858-1919-Career in the Navy-Congresses.

4. Spanish-American War, 1898-Influence-Congresses. I. Marolda, Edward J.

E727.T47 2001

973.8'9-dc21

2001032757

A catalogue record for this book is available from the British Library.

Design by Letra Libre, Inc.

First edition: October 2001

$\begin{array}{llllllllll}10 & 9 & 8 & 7 & 6 & 5 & 4 & 3 & 2 & 1\end{array}$ 


\section{Contents}

Preface

EDWARD J. MAROLDA

1. Theodore Roosevelt, the Navy, and the War with Spain ANNA K. NELSON

2. New Interpretations of How the USS Maine Was Lost DANA WEGNER

3. The Spanish Navy and the Spanish-American War

Rear Admiral Miguel A. Fernandez, Spanish Navy

4. Army-Navy Joint Operations in the Spanish-American War GraHAM A. COSMAS

5. Theodore Roosevelt and the Heritage of the U.S. Navy JoHN A. GABLE

6. Roosevelt's Naval Thinking before Mahan

Lieutenant Commander HENRY J. HENDRIX II, USN

7. The Experience of the Spanish-American War and Its Impact on Professional Naval Thought JOHN B. HATTENDORF

8. The Influence of the Spanish-American War on the U.S. Marine Corps JaCK SHULIMSON

9. "The Men Behind the Guns": The Impact of the War with Spain on the Navy Enlisted Force JAMES R. RECKNER

Contributors 



\section{Preface}

The SPANISH-American WAR OF 1898 WAS a TURNING POINT in the development of the United States Navy. For at least a decade before the conflict, forward-thinking American political leaders and naval officers had pressed for the creation of a fleet of modern, steel-hulled warships armed with the most powerful weapons. Chief among these advocates for a "new Navy" were Theodore Roosevelt, an accomplished naval historian and Assistant Secretary of the Navy; and Captain Alfred Thayer Mahan, persuasive champion at the Naval War College of a strategic theory whose central concept called for command of the sea by an oceangoing fleet of battleships.

The swift and overwhelming U.S. victory in the war validated the views advanced by Roosevelt, Mahan, and other proponents of naval expansion. The American navy, despite problems coordinating all of its operations with the U.S. Army and hitting enemy ships with its gunfire, handily destroyed the Spanish naval squadrons at the battles of Manila Bay and Santiago de Cuba. The Spanish government understood that loss of sea control had doomed its insular empire and promptly sued for peace. Almost overnight, the United States acquired control of Spain's overseas possessions in the Caribbean and the Western Pacific.

The war also had a marked institutional impact on the Department of the Navy in the early years of the twentieth century. Mahan, Stephen B. Luce, Henry C. Taylor, William S. Sims, and other reformist officers pressed successfully for improved management, administration, and logistical support of the Navy and for professionalization of the officer corps. American sailors enjoyed the adulation of the public for their martial performance in the war. Ironically, life in the service for most enlisted men changed little as a result of the victory. Rigid discipline, racial and ethnic discrimination, and the rigors of shipboard life hurt reenlistments and sent desertion rates soaring. The experience of the Spanish-American War provided the U.S. Marine Corps, searching for an expanded mission at the turn of the century, with powerful ammunition. The hard-fought defense of the anchorage at Guantánamo by 
Lieutenant Colonel Robert Huntington's 1st Marine Battalion won the admiration of many Americans and provided an example of how similar Marine units could protect the fleet's advance bases in the newly won overseas empire of the United States.

The Spanish-American War was a defining event not only in the evolution of the Navy and Marine Corps but in the life of Theodore Roosevelt. The future commander in chief burnished his considerable political and intellectual skills with a demonstration of leadership and bravery under fire at San Juan Hill and El Caney. This personal experience and the strategic success achieved by the Navy exerted powerful influences on President Roosevelt's subsequent "big stick" foreign policy. Moreover, Theodore Roosevelt's enthusiasm for the Navy and the sea lived long after him in the extended Roosevelt family, and especially in his illustrious cousin Franklin Delano Roosevelt.

Victory over the Empire of Spain in this short, sharp conflict marked America's debut on the world stage. An energetic, self-confident, and determined generation of Americans then considered it their duty to spread the blessings of democracy, Christianity, and unbridled capitalism to the world and carve out a place for the United States alongside the great powers of the globe. President Theodore Roosevelt was the driving force behind that ethos, and the U.S. Navy was its symbol.

In commemoration of the Spanish-American War of 1898, on October 21, 1998, the Theodore Roosevelt Association, the U.S. Navy Memorial Foundation, and the Naval Historical Center sponsored a symposium entitled "Theodore Roosevelt, the U.S. Navy, and the Spanish-American War." The daylong event was held in the U.S. Navy Memorial's Naval Heritage Center in Washington, D.C. A highlight of the event was an inspiring address by The Honorable John H. Dalton, Secretary of the Navy. Participating in the conference were the Spanish Ambassador to the United States, The Honorable H. E. Antonio de Oyarzabal, and military attachés of the Spanish Embassy. Throughout the day, scholars distinguished by their broad understanding of Theodore Roosevelt, his dynamic impact on the development of the U.S. Navy, and the 1898 war between the United States and Spain presented new interpretations of their subjects. Professor H. W. Brands, author of T. R.: The Last Romantic, presented an insightful luncheon address. A reception hosted by the sponsoring organizations concluded the memorable symposium.

Special thanks are due Lawrence H. Budner, President, Theodore Roosevelt Association; Rear Admiral Henry C. McKinney, USN (Ret.), President, U.S. Navy Memorial Foundation; and Dr. William S. Dudley, Director of Naval History, for their gracious sponsorship of this symposium. Also deserving of thanks is Professor Douglas Brinkley of the Eisenhower 
Center at the University of New Orleans, who reviewed these proceedings; Dr. Maria Zehren of the U.S. Navy Memorial, who helped coordinate the event; and Ms. Debbie Gershenowitz of Palgrave, who used her considerable editorial skills to place this scholarly work before you.

Edward J. Marolda 